\title{
OPERATIONAL MECHANISM OF KARST SPRING "LOGARAS", NEAR THE VILLAGE “SKORTSINOU”, ARCADIA, (PELOPONNESUS)
}

\author{
Karalemas N. and Lekkas S. \\ National and Kapodistrian University of Athens Faculty of Geology and Geoenvironment Department of Dy- \\ namic, Tectonic \& Applied Geology,Panepistimioupolis, Zografou 15784 ATHENS, Greece, \\ nkaralem@geol.uoa.gr,slekkas@geol.uoa.gr
}

\begin{abstract}
This paper presents information on the behavior of the Logaras karst spring, which is located 2.5 $\mathrm{km}$ north of Skortsinou village of the Municipality of Falaesia. This spring discharges the water table hosted in the carbonate rocks located in the area among Skortsinou, Petrina, Soulario and Voutsaras Villages. This area consists of thin-platy limestones of Pindos Unit that overlay the "First Flysch" formation, which is the stratigraphic bedrock of the aforementioned limestones. Aiming at the accurate determination of the boundaries of the spring's hydrological basin, the geological map of I.G.M.E., sheet "Megalopolis" (Papadopoulos 1997 xaı Luettig \& Vingen 1964) was re-examined. The geological and tectonic observations that derived from this process contributed to the analysis of the spring's mechanical operation. This led to the conclusion Logaras Spring is a contact spring. Furthermore, discharge measurements of the spring took place for the period from 24/6/2006 to 26/10/2007 and the relevant hydrograph was drawn, from which the recession coefficient was calculated. More particularly, the spring's recession coefficient for the hydrological years $2005-2006$ and $2006-2007$ is $1,9 \cdot 10^{-3}$ and $4,3 \cdot 10^{-3}$ respectively, while the dynamic volume reach $5,4 \cdot 10^{6} \mathrm{~m}^{3}$ and $1,7 \cdot 10^{6} \mathrm{~m}^{3}$ respectively.
\end{abstract}

Key words: Karst springs, operational mechanism, recession curve, Arcadia, Peloponnesus.

\section{Introduction}

In this paper, the karst system located in the area among Skortsinou, Petrina, Soulario and Voutsaras Villages, southern Prefecture of Arcadia, is studied. This karst system is developed in thinplaty limestones of Pindos Unit, the majority of which are drained by Logaras Spring, located 2.5 km southern of Skortsinou Village (Fig. 1a).

In terms of this project, on-site research was conducted, through which the geological map of I.G.M.E., sheet “Megalopolis" (Papadopoulos 1997 xal Luettig \& Vingen 1964) was re-examined. The stratigraphic and tectonic observations that derived from this process contributed to the determination of the spring's mechanical operation. Furthermore, discharge measurements of the spring took place for a period longer than a hydrological year. The subsequent data processing and analysis led to the calculation of the spring's recession coefficient and dynamic volume; and provided information regarding the water flow within the karst aquifer and the behaviour of the spring.

This work was carried out in terms of the $\mathrm{PhD}$ thesis of the author, Nikolaos Karalemas, a thesis that is supported by the Research Project titled "Decision Support System for the Protection and Man- 


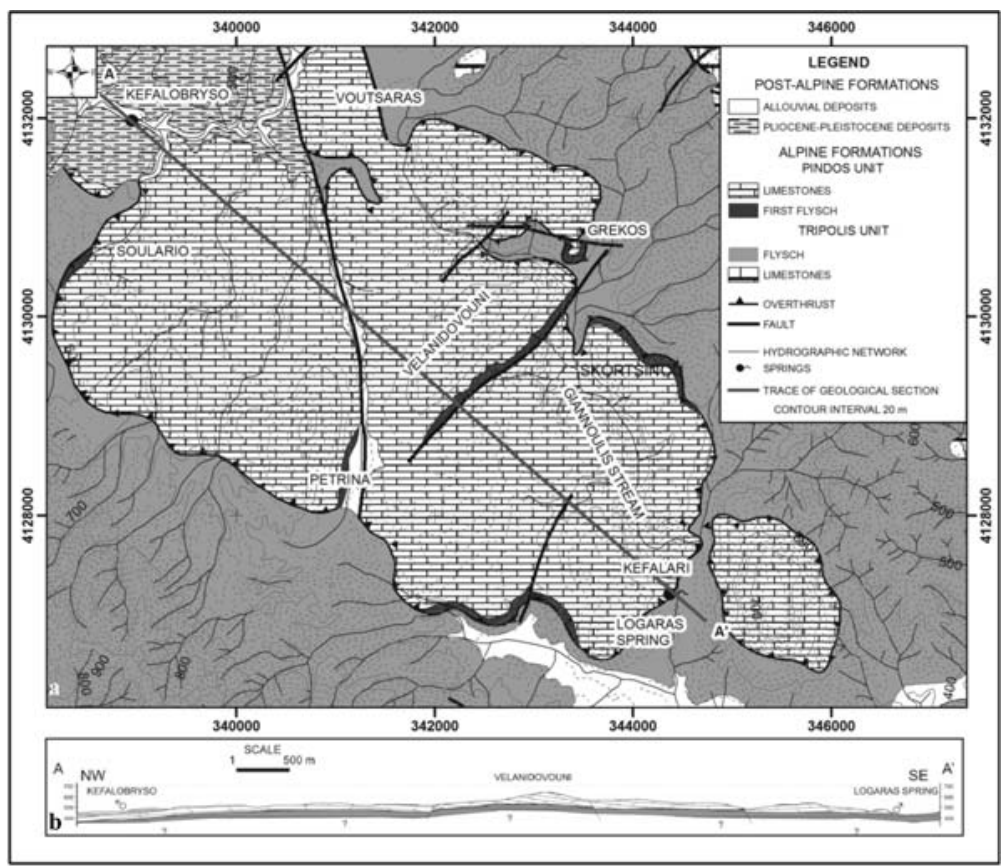

Fig. 1: (a): Geological map of the area of study (Papadopoulos 1997 xal Luettig \& Vingen 1964). (b): Geological cross-section showing the operational mechanism of the springs discharging the carbonate nappe in study.

agement of Water Resources of Lakonia Prefecture by means of Geographic Information Systems" (PENED, 2003). This project is co-financed by $90 \%$ by National and Community Funds ( $25 \%$ from the Greek Ministry of Development-General Secretariat of Research and Technology and 75\% from E.U.-European Social Fund) and $10 \%$ by DEVELOPMENT CORPORATION OF PREFECTURE OF LAKONIA, REGIONAL DEVELOPMENT COMPANY OF PARNONAS and DEVELOPMENT CORPORATION PARNONA - TAYGETOY.

\section{Geological Conditions}

The area of study consists mainly of alpine formations of Tripoli and Pindos Units, as shown in the map (Fig. 1a). The stratigraphic column of Tripoli Unit consists of three parts (Karotsieris and Lekkas 1988), (Georgoulis, 1989): The lowest part comprises slightly metamorphic formations, known as Tyros Beds, which underlie a sequence of carbonate rocks of neritic facies from the Upper Triassic to the Upper Eocene. This sequence of bitumenous thick-bedded to unbedded limestones and dolomites are known as Tripolitza kalk (Philippson, 1892). The upper part is the flysch of the unit, the sedimentation of which started in the Upper Eocene. The formations of Tripoli Unit found in the region of interest are mainly flysch, and in a small extent limestones, the latter shown at the northeastern part of the map. It must be noted that these limestones are hydrologically irrelevant to Logaras Spring. Tripoli Unit tectonically underlies Pindos Unit.

Moreover, only the upper section of Pindos Unit, known as "Arcadian Nappe", is found in the study area and more particularly the following formations: the lowest stragraphic layer is a clastic sequence of sandstones, pelites, and radiolarites in alterations with brecciated limestones of cenomanian age, known as "First Flysch" (Aubouin, 1959). The overlaying formation consists of platy 
limestones with Globotruncanidae. This section of the unit is the most widely found in the central and southern part of Peloponnesus (Dercourt, 1964), (Fleury, 1980). Over the limestones, lie flysch transitional beds and finally, the flysch of the unit. Only the "First Flysch" and the upper cetaceous limestones appear in the area of interest.

The limestones of Pindos Unit contain high amounts of siliceous elements that obstruct the flow of the karst water. Also, the nature of these formations renders them particularly plastic; as a result, they are found intensely folded, and in some cases, the stratigraphic column appears inverted.

The post-alpine formations occupy a limited surface in the northwestern part of the area of study. These formations consist of Pliocene and Pleistocene deposits of the southeastern part of Megalopoli tectonic trough, and more particularly, of marls, clays, sands and slightly cohesive conglomerates in alterations (Luettig \& Vingen 1964). At some locations, thin holocenic allouvian formations, mainly along streams, appear overlaying the aforementioned.

The area of study constitutes a tectonic nappe of Pindos Unit limestones of an area of $21.7 \mathrm{~km}^{2}$, overlaying the "First Flysch", which is practically the impermeable ground of the hydrogeological basin in study. At several locations, where the "First Flysch" does not exist, the tectonically underlying flysch of Tripoli Unit is the impermeable ground.

Tectonically, the limestone nappe appears strongly deformed, due to folds. Furthermore, the area of study has been subjected to intense neotectonic tension, since it is located between the neotectonic horst of Taygetos and the neotectonic trough of Megalopoli, resulting in faults influencing the carbonate formations. These faults are considered to play a minor hydrogeological role.

\section{Hydrogeological Conditions}

The data above show that within the area of study, formations of two types of hydrogeological behaviour can be found in general. The formations of the "First Flysch" and the flysch of Tripoli Unit can be characterized as one type of hydrogeological behaviour and the limestones of Pindos Unit as the second one. The formations of the first type are characterized as low permeable at various locations, but they are practically considered as impermeable rocks, since they are much less permeable than limestones.

On the other hand, the limestones of Pindos Unit are karst formations of high permeability. However, these limestones are not karstified as intensely as other limestones (e.g. the limestones of Tripoli Unit). This phenomenon is owed to the following parameters: the nature, the deposition phase, the layers and the high content in clay minerals of these formations. Therefore, the limestones of Pindos Unit are less permeable than other limestones; nevertheless, they still are karst aquifers. Since the limestones of Pindos Unit overlay impermeable formations, a karst aquifer is generated within the limestones.

The limestones that constitute the nappe under study are relatively isolated hydrogeologically, because the impermeable bedrock extends perimetrically around the nappe. The high amounts of water discharged by Logaras Spring, as well as the fact that the flysch of Tripoli Unit in the wider area is of great thickness, prove that a hydraulic contact between the limestones of Pindos Unit and other underlying limestones does not exist.

Conversely, in the northwest section of the area of study, the limestones are in contact with postalpine formations of Megalopolis basin that are semipermeable. In this case, the limestones communicate hydraulically with post-alpine formations. 
The aquifer hosted in the carbonate nappe, is mainly discharged by two springs. The largest quantity is discharged by Logaras Spring, which is located at an altitude of $430 \mathrm{~m}$ at the site called "Kefalari", on the southeastern border of the nappe. The second spring is located on the northwestern border of the nappe, at an altitude of $455 \mathrm{~m}$, at the site called "Kefalovriso". The positioning of these springs demonstrates a synclinal structure of the impermeable ground of NW - SE direction, along which an underground drainage line is created. The quantities of water discharged by the springs show that the nappe is mainly discharged from Logaras Spring; only a small part of the nappe is discharged by the spring at "Kefalovriso". The difference in altitude of the two springs combined with the difference of their mechanical operation (Fig. 1b) indicates why the biggest part of the karst aquifer is discharged by Logaras Spring: Logaras Spring is a typical contact spring as the water that moves along the geological contact between permeable and impermeable rocks is discharged at its lower point. On the contrary, the second spring is an overflowing spring, since the post-alpine formations overlay the karst formations at the site "Kefalovriso". As a result, the ground water accumulates in a basin that is created in the limestones, between the impermeable bedrock and the post-alpine formations. The post-alpine formations present lower permeability in comparison to the karst formations. Consequently, a small amount of water drains to the water tables developed within the post-alpine formations and the remaining amount of water is discharged by the spring.

The existence of an underground watershed between the hydrogeological basins of the two springs can not be proved by the existent geological data, since the contact between permeable - impermeable, in the middle of nappe, has a very low slope, as shown at the geological cross-section (Fig. 1b). This makes the identification of the direction of its slope impossible. Nevertheless, these springs can operate even without the presence of an underground watershed. In this case, the aquifer is discharged by Logaras Spring at all times, and the operation of the spring at "Kefalovriso" starts only when the level of the water table rises over the altitude of the overflowing spring.

\section{Discharge measurements - data processing}

The discharge measurement conditions of Logaras Spring are ideal, partly due to the constructions made at the area of the spring. More particularly, a lake deep enough is observed on-site, on the southern boundary of which an open channel of $2.2 \mathrm{~m}$ width and $17 \mathrm{~m}$ length is found. The discharge measurements took place in the middle of this channel. At some point, this channel is divided in two branches that may lead the water either to sites where it can be used for irrigation or to the nearby stream feeding Evrotas River. Despite the fact that the channel has a concrete floor, the latter was covered with pebbles, gravel and more detailed material, which were removed with hand tools in order to render the measurements more accurate. These works were repeated before each measurement. The great water supply of the spring, combined with the fact of a constructed channel, led to the selection of the following discharge measurement equipment: Valeport Limited "Braystoke" BFM001 Current Flow Meters that were provided by the Laboratory of Tectonic and Geological Mapping of Department of Dynamic, Tectonic \& Applied Geology of University of Athens.

The discharge measurements of the spring began on 26/4/2006, took place approximately every fifteen days and were continued until 26/10/2007. In the summer of 2007 the region northern of the spring was burned by fires that destroyed a great part of Peloponnesus. This fact combined with the heavy storms that occurred in subsequent November caused flooding phenomena of great intense. Large amounts of water that carried large amounts of solid materials were conveyed through the hydrographical network upstream of the spring, causing disasters (Fig. 2a) and leading to flood of the area of the spring. As a result, large amounts of mud were transferred in the lake (Fig. 2b) and 

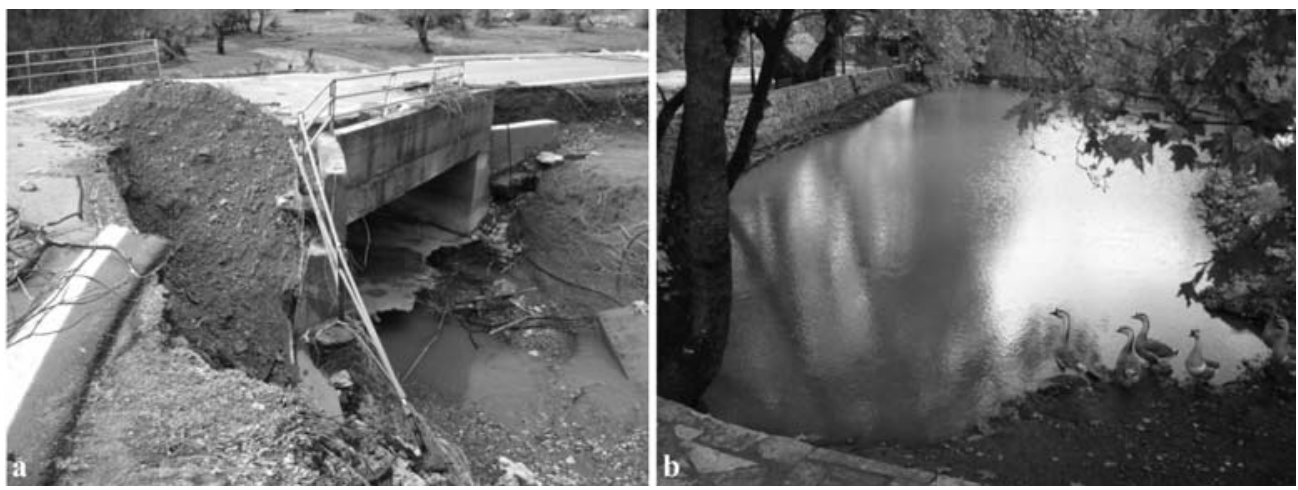

Fig. 2: (a): Disasters caused to Giannoulis Stream, upstream Logaras Spring by the storms of November 2007. (b): The lake formed at Logaras Spring, with muddy water after storms and the subsequent floods of November 2007.

the channel in which the flow measurements were taking place. As it was observed, the water flowing within the channel was muddy for a period greater than a month. Moreover, residues of the aforementioned solid materials remain both in the lake and the bottom of the channel until today. Therefore, the discharge measurements were stopped in October 2007 (548 days from the initiation of the discharge measurements).

The spring's hydrograph (Fig. 3) shows that the greatest discharge rate $\left(1748 \mathrm{~m}^{3} / \mathrm{h}\right)$ was recorded at the first measurement, on 26/4/2006, which is indicative of the water shortage that prevailed during the following year. During the period that follows, the discharge rate decreases steadily until $19 / 10 / 2006$, excluding the period from $8 / 7 / 2006$ to $16 / 8 / 2006$, during which the reduction rate of the flow declines. The recession of the spring seems to start on 19/10/2006. The commencement of the spring's recession appeared in a period later than expected, which is owed not only to large volume of precipitation that the region accepted during the hydrological year 2005 - 2006, but also to the increased rainfall occurrences during that summer. Subsequently, the recession curve continues a steady incline until $25 / 1 / 2007$. After that, a very low value $\left(310.5 \mathrm{~m}^{3} / \mathrm{h}\right.$ ) of the discharge rate (under the extension of the recession curve) was measured, because of the prolonged period of drought that occurred. It is possible that this value is not actual and that it is so low, because the flow was measured after the pumping of the water of the lake, that usually takes place in the summer time. The rainfall of February 2007 is responsible for the initiation of the increase of the curve of the hydrograph for the next hydrological year. Apparently, this rising of the curve was moderate, since it continued (with a maximum value of $585 \mathrm{~m}^{3} / \mathrm{h}$ ) until 1/3/2007. After this date, the curve descended continuously until $23 / 6 / 2009$, when it is estimated that the recession curve starts. From 1/3/2007 to $23 / 6 / 2007$, the curve descends unevenly with numerous rate variations. This phenomenon is due to the scattered heavy rainfalls that occurred in the region during this dry year.

Since August 2007, the hydrograph has an irregular appearance, due to fires that occurred in the region. By extinguishing these fires, large quantities of water were drawn from both the lake located at the area of the spring and the drillings that are fed from the water table discharged by the spring. This resulted in the unexpected reduction of the spring's discharge rate in September 2007. Naturally, the aforementioned acts disturbed the balance of the hydrogeological system in the area of study.

The decline of the rate of reduction of the water supply during the first falling curve is particularly remarkable. This phenomenon is interpreted as an interruption of the groundwater supply in the 


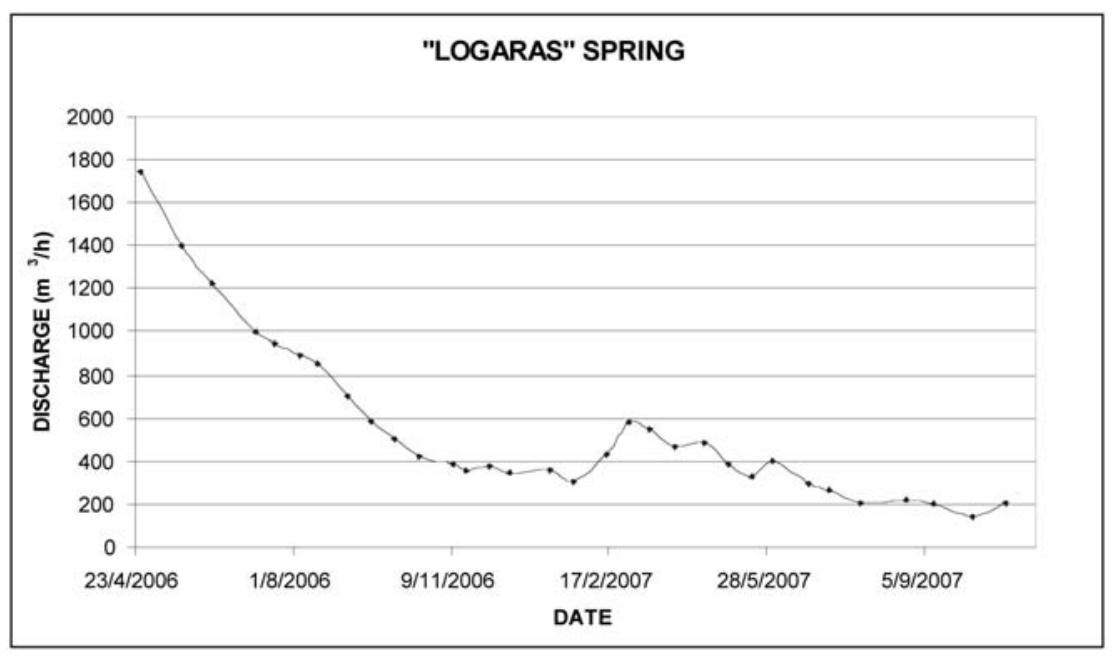

Fig. 3: The hydrograph of Logaras Spring.

karst system by another water body (Soulios, 1985). Practically, it is estimated that the specific form of this part of the hydrograph results from the intense pumping of drillings fed by the water table discharged by the spring. However, this form does not appear at the second falling curve of the hydrograph, due to the irregularities that take place.

Since recession curve of 2007 stopped abruptly, only the recession curve of 2006 (Fig. 4a) can lead to conclusions and to the calculation of the recession coefficient. Nevertheless, an attempt to process the recession curve of 2007 (Fig. 4b) was made, by excluding values estimated to have been influenced by the fires that took place in the wider area of the spring. Analysis of the recession curves and the use of the following expression:

(Maillet, 1905)

(where: $\mathrm{Q}_{\mathrm{t}}$ is the discharge rate of the spring, $\mathrm{Q}_{0}$ is the discharge rate of the spring at the beginning of the recession curves, $\alpha$ is the recession coefficient and $t$ is the time when the discharge rate $Q_{t}$ was measured) leads to the following equations:

$x \alpha l$

for the years 2006 and 2007 respectively.

Consequently, the recession coefficients for the years 2006 and 2007 are $\alpha_{2006}=0,0019$ and $\alpha_{2007}=0,0043$ correspondingly. These values fall in the category of $10^{-3}$, meaning that the water in the aquifer moves through joints and embedded gaps (Soulios, 1985), which is expected to happen within limestones of Pindos Unit. In any case, the determination of the recession coefficient for more hydrological years is necessary in order to draw accurate conclusions.

Furthermore, an attempt was made to estimate the amount of water stored in the karst system at the beginning of recession. Processing and integration of the equation above results in the following expression:

(Milanovic, 1981) 

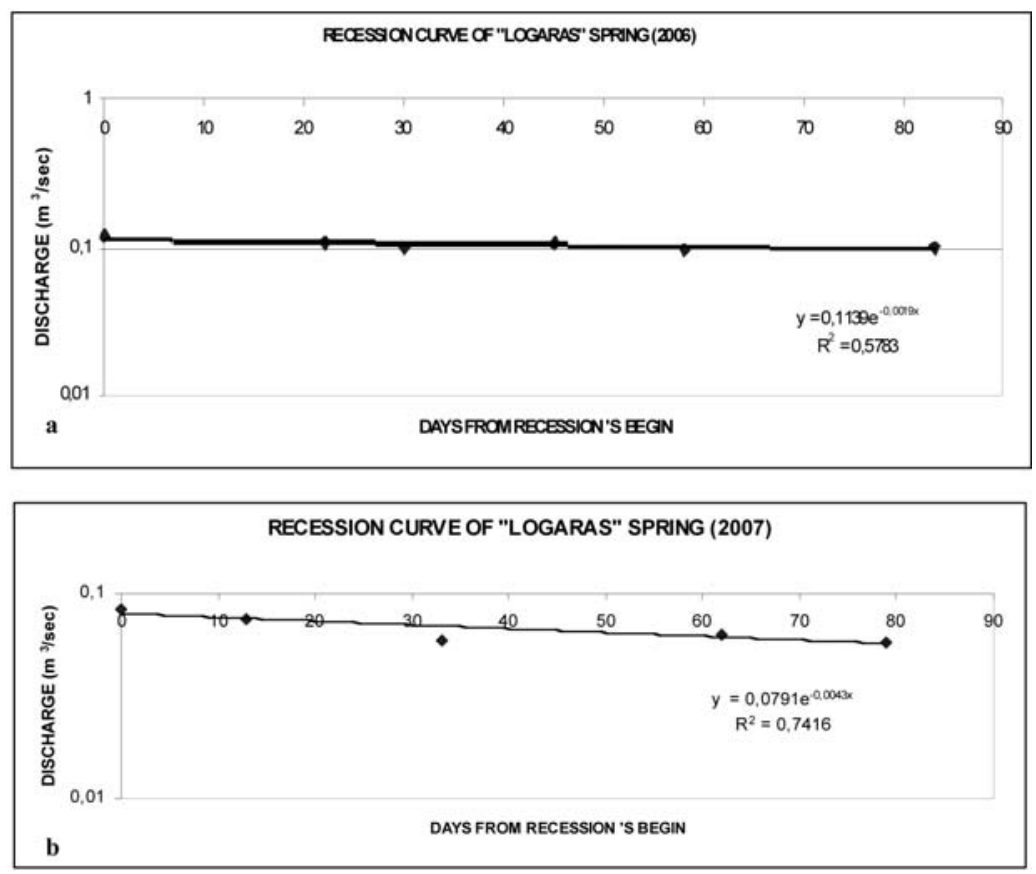

Fig. 4: (a): The recession curve of Logaras Spring (dry season 2006). (b): The recession curve of Logaras Spring (dry season 2007).

(where: $\mathrm{V}_{\mathrm{t}}$ is the dynamic volume, $\mathrm{Q}_{\mathrm{t}}$ is the discharge rate of the spring on time $\mathrm{t}$ and $\alpha$ is the recession coefficient)

By replacing the known values in the formula above:

(Kallergis, 2001)

(where: $\mathrm{V}_{0}$ is the dynamic volume in $\mathrm{m}^{3}, \mathrm{Q}_{0}$ is the discharge rate of the spring in $\mathrm{m}^{3} / \mathrm{sec}$ on time $\mathrm{t}_{0}$, $\alpha$ is the recession coefficient).

According to all the above, the dynamic volume at the beginning of the recession of 2006 was estimated at about $5.4 \cdot 10^{6} \mathrm{~m}^{3}$, while that at the beginning of the recession of 2007 was estimated to be $1.7 \cdot 10^{6} \mathrm{~m}^{3}$. These values are particularly high for the water tables of the area and indicate that the capacity of the water table discharged by the spring is high. However, the significant difference in the values of the storage capacity of the years 2006 and 2007 is indicative of the severe drought that prevailed during the hydrological year $2006-2007$.

Even though this case seems ideal to be used as a natural lysimeter for the calculation of the infiltration coefficient of the limestones of Pindos Unit, practically it is not feasible due to human activities that take place within the hydrogeological basin of the spring, such as the numerous drillings that uncontrollably pump the karst water table of Pindos Unit, removing large quantities of water from the water body; and the wastewaters fed to the water table from the four villages located on the limestones of the spring's hydrogeology basin that have no sewer. 
The fact that fertilizers are used at the cultivations located on the spring's hydrogeological basin combined, with the wastewater of the four villages are responsible for the impaired water quality of the spring compared to other karst waters in the area. On the other hand, because of the large capacity of the aquifer, pollutants are subject to high dilution, resulting in the water quality not to be prohibitive for some uses (the electrical conductivity is maintained at about $600 \mu \mathrm{S} / \mathrm{cm}$ ). In general, it has been observed in the wider region that karst water tables developed in limestones of Pindos Unit are worse in quality than water tables developed in limestones of Tripoli Unit or marbles of Mani Unit (Karalemas, 2006). The lithological variations of these formations, would justify the opposite phenomenon, as the limestones of Pindos Unit are platy limestones, characterized by the strong presence of clay minerals that generally impede the circulation of water and, thereby, reduce its speed and allow its subjection to infiltration. Probably, the difference in quality is owed to the pollution from human activities (settlements, cultivates) that are facilitated on the limestones of Pindos Unit (in opposition to the carbonate rocks of the other units), because of their milder relief, since they erode more easily, and their high concentration in clay minerals.

As mentioned above, the water of Logaras Spring follows the nearby stream and feed the Evrotas River. Specifically, Logaras Spring is one of the main springs of Evrotas River, the other being Vivari Spring located near Sellasia Village of the Municipality of Inounta. This proves the essential role of Logaras Spring to ecosystems in the wider region.

\section{Conclusions}

Summarizing all the above, the following conclusions are drawn:

Logaras Spring is a contact spring that discharges part of the Pindos Unit limestones located in the area among Skortsinou, Petrina, Soulario and Voutsaras Villages, at the southern part of the Prefecture of Arcadia. The spring shows high capacity compared with other springs in the area, which is proved by the fact that the discharge rate for the period from 26/4/2006 to 26/10/2007 ranges from $151 \mathrm{~m}^{3} / \mathrm{h}$ to $1748 \mathrm{~m}^{3} / \mathrm{h}$, especially considering that the correspondent hydrological year was particularly dry.

The hydrograph of the spring determined that the recession coefficient corresponding to the recession curve of 2006 is $\alpha_{2006}=0,0019$, while the recession coefficient of 2007 is $\alpha_{2007}=0,0043$. These values fall in the category of $10^{-3}$, meaning that the water in the aquifer moves through joints and embedded gaps (Soulios, 1985). Also, it was estimated that the dynamic volume at the beginning of the recession of 2006 was approximately $5.4 \cdot 10^{6} \mathrm{~m}^{3}$, while that at the beginning of the recession of 2007 reached $1.7 \cdot 10^{6} \mathrm{~m}^{3}$. These values indicate the high capacity of the aquifer discharged by the spring.

\section{References}

Aubouin, J., 1959. Contribution a l' etude geologique de la Grece septentionale, les confins de l'Epire et de la Thessalie. Ann. Geol. Pays Hell. 10, 526.

Dercourt, J., 1964. Contribution a l'etude geologique d'un secteur du Peloponnese septentrional. Ann. Geol. Pays Hell. 15, 418.

Fleury, J., 1980. Les zones de Gavrovo-Tripolitza et du Pinde-Olonos (Grece continentale et Peloponnese du Nord). Evolution d'une plateforme et d'un bassin dans leur cadre alpin. In: Memoire de la Soc. Geol. Nord, 651.

Georgoulis, J., 1984. Geological and Hydrogeological studies in the Province of Mantinea (Central Peloponnesus). IGME, Hydrological and Hydrogeological Studies 52 (in Greek, the name of author and 
the title were translated in English).

Kallergis, G., 2001. Applied - Environmental Hydrogeology, $2^{\text {nd }}$ Edition. Technical Chamber of Greece, Athens (in Greek, the name of author and the title were translated in English).

Karalemas, N., 2006. Operational Mechanism of Springs of Eastern Taygetos. Master thesis, National and Kapodistrian University of Athens, Greece (in Greek, the name of author and the title were translated in English).

Karotsieris, Z. \& Lekkas, S. 1988. The geological structure surrounding the plateau of Tripoli. Bull. Geol. Soc. Greece. XX(1), 53-66 (in Greek, the name of author and the title were translated in English).

Luettig, G., and Vingen, R., 1964. Bundesanstalt für Bodenforschung, Hannover.

Maillet, E., 1905. Essais d hydraulique souterraine et fluviale. - Herman, Paris, h.t.

Milanovic, P., 1981. Karst hydrogeology. Water Resources Publicatons, Colorado.

Papadopoulos, P., 1997. Geological Map "MEGALOPOLIS" Sheet (scale 1: 50000) I.G.M.E.

Philippson, A., 1892. Der Peloponnes. In: «Versuch einer Landeskunde auf geographischer Grundlage, Berlin, 647.

Soulios, G., 1985. Contribution to the hydrogeological study of the karst aquifer systems of Greece. Aristotle University of Thessaloniki (in Greek, the name of author and the title were translated in English). 